\title{
The effect of pregabalin or duloxetine on arthritis pain: a clinical and mechanistic study in people with hand osteoarthritis [Corrigendum]
}

Sofat N, Harrison A, Russell MD, et al. J Pain Res. 2017;10:

2437-2449.

On page 2443, Table 3, Placebo column, NRS section, the difference was reported as: -0.9 ( -0.2 to 0.2$)$. This is incorrect, and it should read as follows: -0.9 ( -2.0 to 0.2 ).

The Journal of Pain Research is an international, peer reviewed, open access, online journal that welcomes laboratory and clinical findings in the fields of pain research and the prevention and management of pain. Original research, reviews, symposium reports, hypothesis formation and commentaries are all considered for publication.

\section{Dovepress}

The manuscript management system is completely online and includes a very quick and fair peer-review system, which is all easy to use. Visit http://www.dovepress.com/testimonials.php to read real quotes from published authors. 